\title{
第55回 日本細菌学会中国・四国支部総会
}

\author{
会 長: 福井一博 (岡山大学大学院医歯学総合研究科口腔微生物学分野) \\ 会 期：平成 14 年 10 月 17 日（木）・18日（金） \\ 会 場 : メルパルク岡山 (岡山市)
}

\section{特 別 講 演}

病原細菌のゲノムが語るもの……林 英生（筑波大 学基礎医学系)

\section{一 般 演 題}

1. 結核菌感染マクロファージでの細胞質ホスホリ パーゼ $\mathrm{A} 2$ の translocation とリン酸化……佐野 千晶 ${ }^{1}$, 佐野啓介 ${ }^{2}$, 清水利朗 ${ }^{1}$, 佐藤勝昌 ${ }^{1}$, 冨 岡治明 ${ }^{1}$ (島根医大・微生物・免疫 ${ }^{1}$, 同耳鼻咽 喉科 ${ }^{2}$ )

2. 結核菌感染 II 型肺胞上皮細胞による T 細胞の増 殖性応答に及ぼす影響……佐藤勝昌, 清水利 朗, 佐野千晶, 佐野啓介, 富岡治明（島根医大・ 微生物・免疫)

3. 抗酸菌感染で誘導される免疫抑制マクロファー ジのサプレッサー活性発現における PD-L/PD-1 系のかかわり……清水利朗, 佐野千晶, 小笠 原圭子, 佐藤勝昌, 富岡治明（島根医大・微生 物・免疫)

4. Pseudomonas aeruginosa の培養濾液によるマク ロファージのアポトーシス誘導……張 建 嶺, 高山寿雄, 松葉隆司, 田中吉紀（鳥取大 · 医・細菌)

5. CDTB subunit の精製とその機能解析…… 尔 原 勝 $^{1}$, 西久保周一 ${ }^{1,2}$, 井倉正枝 ${ }^{1}$, 藤原 環 $^{1}$, 小松澤均 ${ }^{1}$, 菅井基行 ${ }^{1}$ (広島大 $\cdot$ 大学院 $\cdot$ 医歯薬・細菌 ${ }^{1}$, 歯周病態 $\left.{ }^{2}\right)$

6. Clostridium perfringens ๔-toxin のマウス腎臟に おける局在……五井栄治, 宮田茂, 嶋本聖 子, 松下 治, 岡部昭延 (香川医大 - 医 - 分子 微生物)

7. ウエルシュ菌 $\beta$ 毒素の HL60 細胞障害作用に対
する解析……林 慎也, 森光伸介, 永浜政博, 櫻井 純（徳島文理大・薬・微生物）

8. ウエルシュ菌 $\alpha$ 毒素によるヒツジ赤血球膜破壊 作用と細胞内カルシウム濃度…… 小田真隆, 越智定幸, 櫻井 純 (徳島文理大・薬・微生物)

9. ウエルシュ菌イオタ毒素 $\mathrm{b}$ 成分の細胞結合…… ○山口明雄, 永浜政博, 萩山桐子, 小林敬子, 櫻 井 純 (徳島文理大・薬・微生物)

10. 細菌毒素の腸管上皮細胞への結合と細胞内輸 送……藤永由佳子, 有満秀幸, 阪口義彦, 李 在哲, 太田 圭, 井上 薫, 小熊恵二 (岡 山大 ・大学院医歯学総合・病原細菌)

11. Aeromonas sobria セリンプロテアーゼの産生とシヤ ペロン様タンパク…… 野村知彦 ${ }^{1}$, 小林秀丈 ${ }^{1}$,

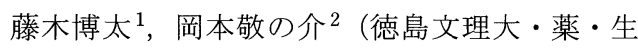
化学 ${ }^{1}$, 岡山大 $\cdot$ 薬 $\cdot$ 分子細胞薬品科学 $\left.{ }^{2}\right)$

12. Aeromonas sobria の産生するセリンプロテアーゼの 血管透過性穴進作用の解析 $\cdots . . .$. 横山律子 $^{1}$, 藤

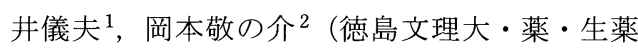
研 $^{1}$, 岡山大 $\cdot$ 薬・分子細胞薬品科学 $\left.{ }^{2}\right)$

13. Aeromonas sobria の産生する溶血毒素の下痢発現 機構……鶴見 健 $^{1}$, 篠田純男 ${ }^{2}$, 三好伸一 ${ }^{2}$, 岡本敬の介 ${ }^{3}$, 藤井儀夫 ${ }^{1}$ (徳島文理大・薬・生 薬研 $^{1}$, 岡山大 $\cdot$ 薬 $\cdot$ 大学院自然科学 ${ }^{2}$, 岡山大 $\cdot$ 薬・分子細胞薬品科学 ${ }^{3}$ )

14. ウシ由来の腸管病原性大腸菌が示す病原性状 ……大平ひとみ ${ }^{1}$, 岡本敬の介 ${ }^{1}$, 根岸友恵 ${ }^{1}$, 有元佐賀恵 ${ }^{1}$, 竹治美穂 ${ }^{2}$, 山中浩泰 ${ }^{2}$, 藤木博 $太^{2}$ (岡山大 $\cdot$ 薬・分子細胞薬品科学 ${ }^{1}$, 徳島文 理大・薬・生化学 $\left.{ }^{2}\right)$

15. USPのIn vitroでの発現とその精製……向村美 幸 $^{1}$, 山本新吾 ${ }^{2}$, 中野政之 ${ }^{3}$, 寺井章人 ${ }^{4}$, 小 川 修 ${ }^{2}$, 倉園久生 ${ }^{1}$ (岡山大 - 医 - 保健 ${ }^{1}$, 京大 $\cdot$ 
医・泌尿器 ${ }^{2}$, 阪大微研 - 細菌感染 ${ }^{3}$, 倉敷中央 病院・泌尿器 4 )

16. 回帰熱ボレリアBorrelia duttonii strain Lyの transmission 解析……牛島陽子, 三谷春美, 福長将 仁（福山大·薬・分子微生物）

17. 新世界及び旧世界回帰熱ボレリアのマウス感染 様式の比較及び抗原変換蛋白遺伝子の解析…… ○川口博史, 田淵紀彦, 福長将仁（福山大・薬・ 分子微生物)

18. ニューキノロン薬耐性Actinobacillus actinomycetemcomitans 検出のための PCR-RFLP 法の検討 ……苔口 進, 井上哲圭, 新垣隆資, 福井一 博 (岡山大 · 大学院医歯学総合 - 口腔微生物)

19. C 型ボツリヌス毒素変換ファージのゲノム解析 ……阪口義彦 ${ }^{1}$, 林 哲也 ${ }^{2}$, 藤永由佳子 ${ }^{1}$, 大 西 真 ${ }^{2}$, 黒川 顕 ${ }^{3}$, 井上 薫 ${ }^{1}$, 村田敬寛 ${ }^{4}$, 中 山恵介 ${ }^{2}$, 有満秀幸 ${ }^{1}$, 小熊恵二 ${ }^{1}$ (岡山大 - 大学 院医歯学総合 - 病原細菌 ${ }^{1}$, 宮崎医大 - 微生物 ${ }^{2}$, 阪大 - 微研 - 遺伝情報 ${ }^{3}$, 信州大 · 医・細菌 ${ }^{4}$ )

20. Bacteroides fragilis $の r r n$ 領域の多型性……岡 田奈津実 ${ }^{1,2}$, 桑原知巳 ${ }^{1}$, 中山治之 ${ }^{1}$, 高麗寛 紀 $^{2}$, 大西克成 ${ }^{1}$ (徳島大 $\cdot$ 大学院医学研究科 $\cdot$ 分子細菌 ${ }^{1}$, 徳島大·工・生物工学 ${ }^{2}$ )

21. Bacteroides fragilisにおける複合糖鎖分解関連遺 伝子群の多様性……中山治之, 桑原知巳, 大 西克成（徳島大 . 大学院医学研究科 - 分子細菌）

22. Helicobacter pylori $\sigma t l p B$ 変異株の行動様式…… ○石川直洋，宗正朋泰，稲津早紀子，溝手朝子 (山口県立大・生活科学・微生物)

23. Vibrio cholerae 0139 逆転写酵素遺伝子欠損変 異と他の遺伝子との関係……竹本祥司 ${ }^{1}$, 島 本 敏 ${ }^{2}$, 島本 整 ${ }^{1}$ (広島大院・生物圏・食品 衛生 ${ }^{1}$, 免疫生物 ${ }^{2}$ )

24. Vibrio mimicus の逆転写酵素と cDNA 産物の解析 $\cdots \cdots \bigcirc$ 高原靖子 ${ }^{1}$, 清野篤子 ${ }^{1}$, 篠田純男 ${ }^{2}$, 島 本 整 ${ }^{1}$ (広島大院 - 生物圈 - 食品衛生 ${ }^{1}$, 岡山 大院・自然科学 $\left.{ }^{2}\right)$

25. Vibrio vulnificusにおける aerobactinによる当該外 膜レセプターの発現誘導機構……阿蘓寛明, 三原和敏, 三好伸一, 山本重雄（岡山大・薬・ 生体情報)

26. Vibrio mimicus における aerobactin オペロンの発 現調節と遺伝子破壊による機能解析……文
瑛華，氏内圭一，三好伸一，山本重雄（岡山大・ 薬・生体情報)

27. Clostridium perfringens $の$ Ferredoxin 遺伝子のべ ントDNA…으. 加地雅人 ${ }^{1}$, 片山誠 ${ }^{2}$, 松下 治 $^{1}$, 岡部昭延 ${ }^{1}$ (香川医大 - 分子微生物 ${ }^{1}$, 岡山 理大・理・生物化 $\left.{ }^{2}\right)$

28. 肺炎クラミジア SET タンパク質の発現解析…… ○村田正之, 三浦公志郎, 東 慶直, 白井睦訓 (山口大・医・生殖・発達・感染医科学)

29. CYP 酵素発現株におけるアントラキノン化合物 による酵素活性の制御……高橋栄造 ${ }^{1}$, 藤田健 $\mathrm{C}^{2}$, 鎌滝哲也 ${ }^{2}$, 岡本敬の介 ${ }^{1}$, 根岸友恵 ${ }^{1}$ (岡 山大 $\cdot$ 薬 $\cdot$ 分子細胞薬品科学 ${ }^{1}$, 北大 $\cdot$ 薬 $\cdot$ 代謝 分析学 ${ }^{2}$ )

30. $N$-ニトロソプロリンの近紫外光 (UVA, UVB) 照 射による NO 生成と変異原性誘起……有元佐 賀恵, 山口明恵, 安東佳子, 岡本敬の介, 早津 彦哉（岡山大・薬・分子細胞）

31. 大腸菌外膜タンパク TolC の輸送機能に関与する 部位…… 藤木博太 ${ }^{1}$, 岡本敬の介 ${ }^{2}$ (徳島文理大 $\cdot$ 薬・生 化学 ${ }^{1}$, 岡山大・薬・分子細胞薬品科学 ${ }^{2}$ )

32. 合成培地で培養した腸炎ビブリオ, NAGビブリ 才，大腸菌の形態変化……古賀哲郎（徳島大 · 医・栄養衛生)

33. Vibrio vulnificus の亜鉛金属プロテアーゼ産生に おけるクォーラムセンシングの関与……河瀬 朋華, 渡辺浩文, 三好伸一, 篠田純男（岡山大・ 大学院自然科学・薬)

34. Actinobacillus actinomycetemcomitans の糖制限ケ モスタット培養における白血球毒素産生促進因 子の解析 $\cdots \cdot . \cdot$ 牛場裕司 $^{1}$, 井上哲圭 ${ }^{2}$, 新垣隆 資 $^{2}$, 福井一博 ${ }^{2}$, 太田寛行 ${ }^{1}$ (茨城大 $\cdot$ 農 $^{1}$, 岡 山大 $\cdot$ 大学院医歯学総合 ${ }^{2}$ )

35. 食水系感染症起因菌の天然水中での挙動…… $\bigcirc$ 藤井み和 ${ }^{1}$, 東海林紀子 ${ }^{1}$, 中野宏幸 ${ }^{1}$, 河本秀 $\mathrm{C}^{2}$, 石村勝之 ${ }^{2}$ (広島大院 - 生物圈 - 食品衛 生 ${ }^{1}$, 広島市衛研・生物科学 ${ }^{2}$ )

36. 土壤中微生物の抗菌因子産生株……高山寿 雄 $^{1}$, 中本幸子 ${ }^{1}$, 井上貴央 ${ }^{2}$ (鳥取大・医・保健 学科 ${ }^{1}$, 医学科 ${ }^{2}$ )

37. anginosus group streptococci 臨床分離株の抗菌薬 感受性……弘田克彦 ${ }^{1}$, 村田広美 ${ }^{2}$, 村上圭 


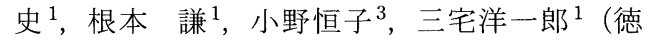
島大 ・歯・ 口腔細菌 ${ }^{1}$, 小児歯科 ${ }^{2}$, 医・ 保健 ${ }^{3}$ )

38. グラム陰性桿菌に対する狭域スペクトル抗菌薬 活用の可能性…‥片岡大輔, 田中吉紀 (鳥取 大・医・基盤病態 $\cdot$ 感染制御)

39. 緑膿菌における新規 RND family 多剂排出ポンプ MexUV-OprW の性質……関谷洋志, 黒田照夫, 水島 徹, 土屋友房 (岡山大・薬・微生物)
40. 種々の口腔レンサ球菌の熱ショック蛋白質 60 遺 伝子の塩基配列の決定とその解析……林 松 男 ${ }^{1}$, 阪口義彦 ${ }^{1}$, 関 鋭 $^{1}$, 藤浪良仁 ${ }^{1}$, 横田憲 治 $^{1}$, 磯貝 浩 $^{2}$, 磯貝恵美子 ${ }^{3}$, 長町栄子 ${ }^{4}$, 小 熊恵二 ${ }^{1}$ (岡山大 $\cdot$ 大学院医歯学総合 - 病原細 菌 $^{1}$, 札幌医大・医・動物実験 ${ }^{2}$, 北医大・歯 · 口腔衛生 ${ }^{3}$, 吉備国際大 ${ }^{4}$ ) 